\title{
Local Wisdom in Kaba Bonsu Pinang Sibaribuik By Emral Djamal Dt. Rajo Mudo: a Heuristic-Hermeneutic Analysis
}

\author{
Hasnul Fikri
}

\begin{abstract}
This study aims to describe four forms of local wisdom found in Kaba Bonsu Pinang Sibaribuik (KBPS) by Emral Djamal Dt. Rajo Mudo. The four forms of local wisdom are (a) philosophy, (b) a social attitude of life, counsel and the message, (c) ${ }^{\text {traditional }}$ ceremonies, and (d) habits or behaviour in social intercourse. The method of this research is qualitative descriptive. The data of this research are words, sentences, and discourses that contain local wisdom in KBPS. Four critical findings of this research are observed. First, local wisdom based on observation are self-esteem, logical reasoning, optimistic, and strong attitude. Secondly, local wisdom based on social attitude is communalism and egalitarian, cooperating, caring, generous and helpful. Third, local wisdom based on ceremony or traditional ceremonies are alua (procedure, way) and patuik (proper), regulation about the procedure and place of discussion, and role of bundo kanduang (queen mother). Fourth, local wisdom based on habits or daily behaviour in social intercourse is prioritizing agreement, putting forward ethics and attitudes, rukun (peaceful), saiyo-sakato (agreement), equality and togetherness, mutual respect and caring, democratic attitude of listening, and unselfishness. It's can concluded that KBPS is a useful source to recognize and understand the local wisdom of the Minangkabau community so it needs to be studied and preserved.
\end{abstract}

Index Terms: heuristic-hermeneutic, kaba, local wisdom, Minangkabau, traditional literature.

\section{INTRODUCTION}

Oral literature, including folklore, is essentially a tradition shared by a particular group of people. Folklore often reveals the socio-cultural conditions of a particular society. Soeratno (2011: 30-31) states that there is information about a life in all its aspects, such as education, social, economic, political, religious, morals, health, history, law, morals, astrology, linguistics, art, mythology, and even matchmaking. In line with Soeratno (2011), Udin (in Emral, 2005: v) argues that oral tradition is a cultural heritage of society because it contains all the discussion thoughts, feelings, and ideas of cultural supporters. Thus, the effort to explore, study, and inventory cultural values and local wisdom in texts derived from oral traditions (such as kaba) is important to find the uniqueness of the text itself.

Kaba is one of traditional oral narrative in the community of Minangkabau, Province of Sumatera Barat, Indonesia. There are four kinds of kaba pusako (heirloom kaba) i.e.: Kaba Cindua Mato, Kaba Malin Dewa nan Gombang Patuanan or Kaba Sutan Pangaduan, Kaba Anggun nan

Revised Manuscript Received on October 15, 2019

Hasnul Fikri, Universitas Bung Hatta Jl. Bagindo Aziz Chan, By Pass, Aie Pacah, Padang Sumatera Barat, Indonesia, hasnul_ubh@yahoo.com
Tongga, and Kaba Bonsu Pinang Sibaribuik Sati. From the four kabas, there are only two that are quite popular and well known, namely Kaba Cindua Mato and Kaba Anggun nan Tongga. Certain interesting episodes of these two kaba are made into songs by tukang kaba or tukang rabab. Kaba is also played in randai story, even processed for modern theater performances (Emral, 2005: ii-iii).

Unfortunately the tradition of storytelling, especially the traditional stories, has diminished based on Hasnul's (2015) research on the tradition of telling the story of Sub-district Mungka, District of Lima Puluh Kota, Province of Sumatera Barat, Indonesia. This research is in line with research of Silvia (2017) which shows that rabab (Minangkabau tradition stringed musical instrument) Pasisia Selatan in Minangkabau is almost extinct, whereas rabab is one form of kaba presentation.

In order to preserve the oral tradition into written form, Emral Djamal Dt. Rajo Mudo (Emral) seeks to recompose some episodes Kaba Pinang Sibaribuik Sati in the form of $k a b a$ original speech, namely in the form of lyrical prose. Emral Djamal Dt. Rajo Mudo is a famous writer, cultural, historian, and activist of silat (traditional self-defense) in Minangkabau. He wrote three poem collections, performed in the Minangkabau theatre, and read poetry at various events. Emral Djamal Dt. Rajo Mudo received awards from the Government of Bukittinggi City in 2010 for his concern in preserving the Art of Silat Minangkabau Tradition and from the Agency of Language Development and Coaching, the Ministry of Education and Culture of Indonesia in 2016 for his concern in preserving the Regional Literature (https://id.wikipedia.org/wiki/Emral

Djamal_Datuk_Rajo_Mudo)

According to Emral (2005: v-vi), the text of KBPS as a Minangkabau oral literature has its own uniqueness. Because of the scarcity of the intact text, he seeks to reconstruct illustrations of disjointed stories based on records unearthed from the narrators and teachers of silat who still remember the kaba. The reconstruction is packed through a story that is generally delivered in the form of lyrical prose. Each array consists of 4-5 words or 8-12 syllables without final rhyme. However, there is also an oral kaba which is entirely conveyed like a rhyme. 


\section{Local Wisdom in Kaba Bonsu Pinang Sibaribuik By Emral Djamal Dt. Rajo Mudo: a Heuristic-Hermeneutic Analysis}

Many elements of value that can be explored to be exemplary of the literature work. One of the elements is local wisdom contained which can be an important asset in building the character of the nation's children. Character building begins from the early of individual development by providing readings that are able to instill good values. In connection with this research, the content of Minangkabau local wisdom can be used as a guide in understanding life.

Based on the aforementioned reasons, the study of the local wisdom in KBPS is important. The main problem that became the focus of this study is how the local content of wisdom is reflected in KBPS? It is assumed that the content of local wisdom in KBPS can be expressed using a combination of textual interpretation theories and sociology of literature. This study will be interpreted specifically the local wisdom content in KBPS according to the approach adopted by Ricoeur (in Kleden 1997: 42; Nyoman, 2009: 242-243; Agustina 2016: 17), i.e. the text (in this case KBPS) can be used as a paradigm to understand and explain human actions and experiences. By using the text as a paradigm, in essence, Ricoeur says that the most important goal of textual interpretation is not merely to understand the meaning of the text itself, but to understand the existence of human being and his world.

\section{LITERATURE REVIEW}

A literary work is a tool for conveying the author's vision, mission, ideology, and opinion to something he sees, feels, observes, and thinks about. As a medium that is formed from the creative work, the object of literary work is human with all the problems of humanity (socio-cultural aspects). Sapardi (2012: 1) said that literary works always display a picture of life, while life itself is a social reality. Thus, all aspects of human life with its culture are in the literature, including the content of local wisdom that is reflecting the culture of the local community. By studying and concluding what is in the local colour literature, both in terms of form (language) and content (theme and message), the reader can understand the cultural diversity of the ethnic uniqueness. Studying literary works of a certain cultural background, for example Minangkabau literary works, can develop a reader's understanding of the diversity of the culture.

Literary works as imaginative-creative works display various phenomena of life, including the content of local wisdom. This phenomenon is an event that occurs in society or a reflection of real life. The author uses his story material from events that take place in life through the process of seeing, hearing, reading, and even experiencing it himself. The event is processed, embellished, and polished with a variety of imagination to form a story. It is this process which produces the story as a new world or a symbol world and to understand it is necessary interpretation. Although the story (literary work) is only a world of symbols, at least from the world of these symbols the ideology it contains can be observed. Departing from that thought, it is clear that in the literary work is reflected ideology as a cultural fact. This is in line with Hoggart's opinion (in Agustina, Syarul and Yasnur, 2016: 16) who feels that literary works contain ideology and cultural values applied. Therefore, what the author does in his

work is the problems related to the lives of individuals in the structure of society. Then, it should also be remembered that the author is a product of the times and the environment. Therefore, at least, the writers' minds are also influenced by that time and environment. The idea in his mind transformed through the characters of the story. Thus, literature means the pronunciation of a cultural experience as a cultural expression. Literary works are a product of wisdom that is able to provide enlightenment for anyone who appreciates it. Humans psychologically tend to like the story. Therefore, literary works can enrich the life of the audience either through reading, writing, listening, and discussing it. Directly or indirectly, literature enriches the reader's life through the enlightenment of experience and the problems present in it and its solutions. Meanwhile, Abdurrahman (2014: 44) said that the message of local wisdom in Minangkabau in Kaba has the distinction and unique because it is associated with Minangkabau cultural philosophy and life view.

Related to local wisdom, Djamaris (in Agustina, Syarul \& Yasnur, 2016: 15) said that the Minangkabau people appreciate people who are friendly, humble, and spiritual but hate angry and arrogant people. The values, ethics, and behaviours that serve as the source of policy can be called with local wisdom. Agustina, Syarul and Yasnur. (2016: 15) said that the literary work is a reflection of the life of the society that underlies the literary work. As a reflection, a literary work is a cultural product and plays an important role in human life. In literature, there are possibilities or alternatives to dealing with human life. The point is that literary works provide alternatives for responding the life artistically imaginatively. This is possible because in the literature, discussion about human and cultural issues, such as marriage, education, inheritance, loyalty, treason, heroism, sorrow, joy, deceit, corruption, wickedness, arbitrariness, and rape of human rights was presented by the writer through their works. Thus, a literary work is a reflection of the life of the community (both local and global) which lies behind literary works with various content of local wisdom, such as values, ethics, and behaviours that serve as a source of policy.

The semiotic reading method of Riffate (in Rina, 2016: 6-7) includes (1) heuristic readings, (2) hermeneutic readings, (3) matrices, models, and variants, and (4) hypogram. Heuristic readings are readings based on language systems and conventions. This heuristic reading is the first stage reading that moves from the beginning to the end of the literary text. The reading of this first stage will produce a series of heterogeneous meanings. Hermeneutics or retroactive readings are based on literary conventions. At this stage the reader can describe the meaning of literary works based on the first interpretation by moving further to obtain the unity of meaning. According to Ricoeur (in Nyoman, 2009: 242-243) the main task of hermeneutics is to understand the text. To understand the text as a social reality is necessary two stages, namely explanation and understanding. To clarify, it requires three stages, namely the stage of the semantic, the reflection, and the existence. 
The hermeneutical readings start from thinking that a text has a contextual relationship. The hermeneutic aesthetic keyword is a dialogue between text and context in an interpretive technique called the hermeneutic circle because the process of dialogue with the context is done many times to find the legitimate and convincing meaning (Saifur, 2012: 20-21).

There are some studies that are relevant to this research. First, Abdurahman (2014) had studied the message of educational character wisdom in the Minangkabau classic story. He found that in Kaba Cindua Mato there are some aspects of education wisdoms consist of the importance of education, education strategy, learning passion, not discriminate, ethics, prayer and knowledge of faith education, and educating children in various opportunities.

Second, Agustina, Syahrul Ramadhan, and Yasnur Asri (2016) had studied local wisdom in the modern short stories by Minangkabau writers. Based on their research, local wisdom in short stories has a local view based on knowledge of life (philosophy), local wisdom based on an attitude of social life, ceremony by mutual assistance standards and rules and regulations, and local wisdom based on habits.

Third, Sony Sukmawan (2017) had studied environmental wisdom in the oral literature of Arjuna Slopes People and found that the range of oral literature texts of Arjuna Slope communities explicitly and implicitly, intensively and extensively, show the orientation towards nature. The study also reveals the presence of the biological and the psychological nature which are conveyed explicitly and demonstrated in its vitality.

Fourth, Ngismatul Khoeriyah, Warto, and Sariyatun (2017) had studied learning history integrated local wisdom values Babad Banyumas to build students' national identity. The research found that Babad Banyumas has values that match the character's learning, such as social values, the moral value, and the religiosity value that includes spiritual attitude.

Fifth, Firdauzia Nur Fatimah's (2017) research on local wisdom values in Sayu Wiwit folklore as the revitalization of behavioral education. This study found that the values of local wisdom that can be taken from the Sayu Wiwit are confidence, creativity, and positive behaviours. The manifestation of behavioural education leading to nationalism can be seen through the values of local wisdom in Sayu Wiwit.

The five research shows that local wisdom can be found in literature work, both oral and written literature, traditional literature, and modern literature. In other side, the objects of these three researches are different from objects in this research. So, this research completes another research on local wisdom in literature.

\section{METHODS}

The method of this research is qualitative descriptive. The data of this research are words, sentences, and discourse that contains local wisdom in KBPS. The object of this research is KBPS. Selection of research object is done by considering the following: (1) focus of research, namely the content of local wisdom in KBPS; (2) the level of Kaba's literary values;
(3) the integrity and popularity of the author; (4) influence on society, Kaba which become object influential to the attitude and way of view of the local community.

Data collection is done by reading-record technique. Collecting and analyzing data is done in a concurrent way so that the data can be validated triangulation with the data source. This is in accordance with Lexy's opinion (2002: 104) that data analysis is done in one process with data collection. Thus, the research instrument is the researcher himself, who is assisted by the identification format and data classification.

Data analysis was done by content analysis method and heuristic-hermeneutic reading method. Content analysis techniques are used to extract the contents, the messages contained in the object of research, and give meaning to the message contained in it to describe the social phenomenon that occurs. This is in accordance with the opinion of Suwardi (2011: 160) which says that analytical techniques in the field of literature can be used to understand literary works that include extrinsic elements, such as moral messages, educational values, philosophical values, religious values, and others. The steps of the analysis are as follows. Firstly, read, inventory, and identify intensively the story motives that can be abstracted as the content of local wisdom in KBPS. This stage produces a series of notes, including quotes that prove the content of local wisdom expressly or implicitly in KBPS. Secondly, make a creative interpretation of the content of local wisdom found in KBPS. Thirdly, summarizes the results of the interpretation to obtain an overview of the content of local wisdom conveyed by author through KBPS. Fourth, connecting the forms of local wisdom in kaba (fictitious reality) with public opinion on the local content of wisdom contained in society (objective reality). Fifthly, prepare a research report.

\section{RESULTS AND DISCUSSION}

There are four forms of local wisdom found in KBPS. The four forms of local wisdom are based on: (a) view of life (philosophy), (b) the attitude of social life, advice, and message, (c) custom ceremonies, and (d) habits or daily behavior in social intercourse.

\section{A. View of Life (Philosophy)}

Local wisdom based on life view in KBPS is explained based on the findings of the following data.

1. jikok tacoreang arang pado badan, dapek disaok jo kain baju, tapi kok tacoreang pado kaniang, muko kamano disuruakkan lai, malu denai dek kakak, bak itu sajak dulunyo, pasan pitaruah mande kito.... (Emral, 2005: 24)

(if charcoal smeared to the body, can be covered with clothes, but if smeared on the forehead, where the face should be hidden, I am ashamed, my sister, like that our mother's message for a long time)

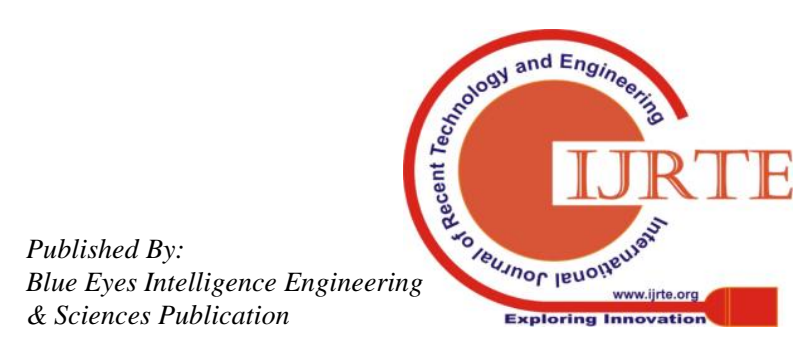




\section{Local Wisdom in Kaba Bonsu Pinang Sibaribuik By Emral Djamal Dt. Rajo Mudo: a Heuristic-Hermeneutic Analysis}

2. malu tacoreang pado badan, dapek dilampok jo kain kain baju, kini tacoreang pada kaniang, kama muko denai suruakkan. (Emral, 2005: 354)

(shame smudged into the body can be covered with a shirt, now embarrassed smudged into the forehead, where the face should be hidden)

3. Malu manimpo diri ambo, arang tacoreang pado badan dapek ambo lampok jo kain baju, kini tacoreang pado kaniang, kamano muko ambo suruakkan (Emral, 2005:359)

(I am ashamed, if charcoal smeared into the body, it can be covered with clothes, but now smudged to the forehead, where the face should be hidden).

In quotations (1), (2) and (3) it is seen that the embarrassing deeds are plastered with charcoal. If charcoal smeared on the body can be covered with clothes, but if smeared on the forehead can't be hidden. Based on the viewpoint of life in Minangkabau, falling self-esteem is an embarrassing disgrace. To hide the shame in maintaining self-esteem, they are taught to be able to assume the risks and consequences, as expressed in the saying tadorong kaki inai padahannyo, muluik tadorong ameh padahannyo (If the leg passed over the limit, henna as punishment. If the mouth is passes over the limit, gold as punishment). That is, anything that can harm or impose the dignity of a person or a person should be accounted for in order not to give shame, either to oneself or to the people, despite the heavy consequences, as expressed in saying "tak aia talang dipancuang, tak kayu janjang di kapiang, tak ameh bungka diasah" (if there is no water, the bamboo will be cut, if there is no wooden, the ladder will be clipped, if there is no gold, clod will be sharpened). That is, the saying teaches humans to be able to overcome the difficulties that are being faced, albeit in quite an extreme way as said in the phrase daripado baputiah mato, labiah elok baputiah tulang (instead of bleaching eyes, better bleached bones). That is, rather than life bears shame it's better "suicide".

However, Minangkabau people should have a logical consideration by holding the mandate hiduik baraka mati bakiro (live with the mind, die with the calculation). If shame caused by the self-esteem had fallen or by the insult from the others, the message taught them to retaliate as revealed in the saying "musuah indak dicari, basuo pantang diilakkan, tabujua lalu, tabalintang patah" (the enemy is not sought but if it meets the abstinence evaded, whatever the risk). That is, Minangkabau people are stimulated to be optimistic in the face of the problem that befell or someone blocked his step.

However, if the person that shamed him is too strong to resist, the saying teaches them "tak lalu dandang di aia, di gurun ditanjakkan juo (if the canoe can't pass through the water, on the desert will be missed too). That is, if "the little" or "the weak" can't reply in the usual way, they can reply in an unusual way.

Data of local wisdom based on life view (philosophy) in KBPS can also be seen in the following quotation.

1. "usah anak hati paibo, bukan sipek urang laki-laki (Emral, 2005: 407)

(boy do not compassion, it is not the nature of men)

The oblique words in the quotation (4) contain the moral message that a boy must be strong, tough, and not easily discouraged. Minangkabau males are not complaining, crying, or denouncing their difficulties to others. To overcome his personal difficulties, he preferred to wander with a pity heart (Ali, 1986: 65).

\section{B. The Attitude of Social Life, Advice, and Message}

Data of local wisdom based on social life attitude, advice, and message in KBPS is explained based on the findings of the following data.

1. baiek budi kucindan murah, urang senteang dibilainya, urang kurang ditukuaknyo, lai panolong pado nan bansek, pamurah pado anak dagang, urang nan suko tolong manolong.... (Emral, 2005: 31)

(good and friendly, if someone short will be extended, if someone's shortcomings will be added, easy to help the poor, not stingy to the wanderers, the people who easy to help...)

Local wisdom based on a living attitude containing advice based on communal and egalitarian is manifested in the form of attitudes toward others. The words are skewed in the quotation (5) indicating that the Minangkabau people are firm in cooperating, caring, generous, and helpful. This is in line with the mean that expressed in the saying duduak surang basampik-sampik, duduak basamo balapang-lapang (sitting alone will feel cramped, sitting together will feel roomy). When life is aloof, people will feel the world is limited because the problems should to be handled alone. Minangkabau people live in groups, as well as, in social, economic, political, and territorial. In the social life group, they organize their lives in small groups of brothers, a group of housemaids united with their blood relatives in other homes.

Brothers in blood from some homes are united with all the descendants of their ancestors. It tends to protect nature. Therefore, Ali (1986: 75) says that the Minangkabau does not use the word unity in their social relations, but by using the term of samo (same) and basamo (together). Therefore, in communal societies, like Minangkabau, all tasks are a shared responsibility. The nature of collaboration (gotong royong) is a shared responsibility. The nature of gotong royong is a must be applied in daily life. Mutual help and support are an obligation, as revealed by the Minangkabau people, namely sapikua sajinjiang (the same load). Quotation (6) shows implication of concept of samo and basamo in Minangkabau community life.

1. malu adiak malu dek denai, susah dek adiak susah dek denai, sanang dek adiak sanang dek denai.... (Emral, 2005: 26)

(if younger sister is embarrassed, older sister is also shy. if young sister is hard, older sister is also difficult. If younger sister is happy, older sister is also happy.)

Mutual social stance and counselling in KBPS can also be seen in the following.

1. ...kaba baiek baimbauan kaba buruak baambauan. (Emral, 2005: 37)

(good news is called, sad news comes alone....) 
Quotation (7) said that if there is good news, such as party, you will come if invited, but there is a sad news, such as dead, you should come without any invitation. The doctrine of social life in the society teaches people to help and understand each other. Their teaching in maintaining a harmonious balance used raso jo pareso (taste and check). If there is a misfortune that afflicts a family, the other family in the community is obliged to tell the bad news to others without expecting the grief to preach their grief as a form of sense of community. That is, everything is measured with the same feelings and worth checking. The criterion of raso or feeling is pain and pleasure. For pain, they use the phrase hukum piciak jangek, sakik dek awak sakik dek urang" (the skin pinch law, if we feel pain other people feel pain too). That is, if a misfortune occurs in a family, another neighbourly family should feel it. Respect is the attitude and way of view that are always guarded by the people, especially in experiencing calamities that cause the thought of lamak dek awak katuju dek urang (what we enjoy should be liked by others too).

\section{Custom Ceremony}

Local wisdom data based on ceremonies in KBPS are explained based on the findings of the following data.

1. rundiang sudah bicaro salasai, bulek aia dek pambuluah, bulek kato dek mupakek, saciok nan bak ayam, sadanciang bak basi....

(Emral, 2005:13)

(...the negotiations are over, round the water because of the vessels, round words because of consensus, one tweet like chicks, one clink like iron...)

Quotation (8) explained that once the negotiations are over, the accord has been taken so that the participants must agree on the outcome of the negotiations. In the case of ceremonies, alua jo patuik (procedure/way and proper) as the basis of the attitude and views of Minangkabau society needs to be considered. Alua (procedure/way) means respecting and obeying the prevailing social hierarchy, batanggo naiak bajanjang turun (using ladders to ascend and descend), and embracing conventional based on budi and sangko (mind and honour). This rule is very binding community in all aspects of community life. Patuik (proper) means worthy, does not violate the norms and rules that apply. In the Minangkabau proverb, often called lamak di awak, katuju dek urang (what we enjoy should also be liked by others).

In relation to alua and patuik, tradition also regulates the matter of the procedure and place of discussion according to custom. For example, the procedure in a discussion, according to custom, a penghulu in order to meeting at balai adat must depart from the rumah gadang of the mother's family because what to talk about at the meeting should be informed firstly with bundo kanduang. After the meeting in the balai adat, the penghulu must return to the rumah gadang to report the results of the meeting to ask whether the meeting results are in accordance with the aspirations of the people. This is actually the procedure that is meant by bundo kanduang pai tampek batanyo pulang tampek babarito (queen mother is the place to ask before leaving and to report after back home). According to matrilineal system,

women are commissioners and men or penghulu are their managers (Ali, 1999).

\section{Habits or Daily Behavior in Social Intercourse}

Data of local wisdom based on daily habits or behaviour in social life in KBPS are following.

1. ...jikok talendo di katurun, jikoknyo tagasie di kanaiek, rila jo maaf dipabanyak, utang nan samo kito lansaikan.... (Emral, 2005: 15)

(... if pushed when down, if shifted when up, sincere and sorry is sought, debt is equally paid off....)

Quotation (9) shown that Minangkabau people aware of others. On the other hand, as humans, they are also aware that they might make a mistake. They did not hesitate to apologize for any mistakes they might have made. If you have forgiven each other, then the debt, as a comparison of errors, considered to be paid off.

Other data about daily habits or behaviour in social interactions can also be seen in the following two quotes

1. ...hukum nan ka dijatuahkan, bak maelo rambuik dalam tapuang, rambuik nan panjang dapek taelo, tapuang taonggok taserak jaan. (Emral, 2005: 66)

(... the law will be decided, such as pulling hair in flour, long hair can be pulled, piles of flour not scattered).

2. ...tarangkan dek adiek jaleh-jaleh nak samo sanang paratian, nak samo sajuak kiro-kiro.... (Emral, 2005:353)

(... describe it clearly to delight the attentive and cool the feeling....)

3. ...sadanciang bak basi, lah saciok bak ayam, bulek kato dek mupakaik, sajangka indak ka denai ansua, sadapo indak ka denai asak, itu tandonyo kato batapati, kato sagalo ninik mamak, kato daulu ditapati, kato kudian kato bacari... (Emral, 2005: 68) (... one clink like iron, one tweet like chicks, round words by consensus, a single span will not be shifted, a single cubit will not be changed, that is the proof of the word kept, the talk of all ninik mamak, preliminary talks be obeyed, the last word is a searchable word (if the initial agreement cannot be executed)

Quotation (10) shows the attitude of mutual respect and caring for the feelings of others is important to note. That is, in pulling a decision, ideally the result of the decision itself is shared, not only to bring disputes against an individual or group. Minangkabau custom always implies to maintain the communication. In quotation (12) it can be seen the wishing for a democratic attitude of listening, mutual respect, unselfishness. Meanwhile, quote (13) shows the manifestation of consensus, either in the form of rule or law.

In relation to daily social habits or behaviour, Minangkabau people prioritize consensus as a way to solve problems. That is, consensus is sincerely reflected by expressing approval of all that their leader decides, proverb states that kamanakan barajo ka mamak, mamak barajo ka panghulu, panghulu barajo ka mupakaik, mupakaik barajo ka alua jo patuik 


\section{Local Wisdom in Kaba Bonsu Pinang Sibaribuik By Emral Djamal Dt. Rajo Mudo: a Heuristic-Hermeneutic Analysis}

(nephew obey to uncle, uncle obey to the penghulu, penghulu obey to the consent, consensus obey to procedure/way and proper).

In contrast to local wisdom based on ceremonies and traditional ceremonies, the intent of this proverb suggests that not only the ordinances of ceremonial execution, but also puts forward ethics and attitudes. The leader of the nephew is the uncle, the leader of the uncle is the penghulu, the leader of the penghulu is a consensus; the leader of consensus is the line of groove and propriety. Although the consensus has been in accordance with the proper lines to be discussed together, the consensus has a rukun (peaceful), namely unanimity. The unity of that word is called sakato (agree), which is a manifestation of consensus decision, in the form of rules and law.

In the sociological sense, saiyo-sakato (agreement) means homogeneity of society based on communal life. Meanwhile, in the sense of constitutionality, it has a democratic meaning. Therefore, the sense of equality and togetherness is higher in value than the agreement. Agreement can also arise because there is a sense of reluctance to express an opinion that is different from the general opinion, while the sense of equality and togetherness put everyone at the same level in the first level. Understanding is based on the point of democratic thinking is dissent does not mean to join with others. The proverb says about the difference of opinion with the expression basilang api ditungku, di sinan nasi mangkonyo masak (if wood crossed in the stove, the rice will be cooked). Lexically, the fire will only burn in the furnace when the wood is placed in a cross, not neatly arranged. Grammatically, this is meant as deliberation or consensus that is required in different minds so that the problem can be solved as best as possible.

\section{CONCLUSION}

Based on the data analysis and discussion, it can be concluded the content of local wisdom contained in the KBPS as follows. Firstly, local wisdoms based on a live view are self-esteem, logical reasoning, optimistic, and strong attitude. Secondly, local wisdoms based on social attitude are communalism and egalitarian, cooperating, caring, generous, and helpful. Third, local wisdom based on ceremony or traditional ceremonies are express the truth based on path and proper and role of bundo kanduang. Fourthly, local wisdom based on habits or daily behaviour in social intercourse is prioritize consensus as a way to solve problems, rukun (peaceful), sakato (agree), sense of equality and togetherness, mutual respect and caring for the feelings of others, and always maintains communication.

\section{RECOMMENDATION}

Based on the above findings, several recommendations are suggested. Kaba lovers are expected to read kaba critically to find the values of local wisdom in it. Stakeholders, i.e. governments, authors, adat leaders, and teachers, are expected to develop young people's appreciation to preserve kaba as part of their ancestral heritage as well as convince them of the richness of thought within kaba. The researcher intends to study local wisdom in another kaba or other aspects of KBPS such as study feminism, ecology, religiosity in kaba.

\section{REFERENCES}

1. Ali Akbar Navis. (1986). Alam Takambang Jadi Guru. Jakarta Pustaka Grafitipers.

2. Ali Akbar Navis. (1999). Yang Berjalan Sepanjang Jalan. Jakarta Grasindo.

3. Abdurahman. (2014). "The Message of Educational Character Wisdom in the Minangkabau Story". Proceeding of The Third International Seminar on Language and Arts, Padang. October, 1/18. $44-53$. Retrieved from http://ejournal.unp.ac.id/index.php/isla/article/ download/ 5309/ 4190

4. Agustina, Syarul Ramadhan and Yasnur Asri. (2016). "Muatan Kearifan Lokal Dalam Cerpen Mutakhir Karya Cerpenis Minangkabau". Jurnal Humanus. Vol. XV No. 1, Maret 2016. 14-31.

5. Emral Djamal Dt. Rajo Mudo (2005). Kaba Pusako Minangkabau; Bonsu Pinang Sibaribuik. Padang: Pusat Kajian Warisan Budaya Minangkabau.

6. Firdauzia Nur Fatimah, Edy Tri Sulistyo, \& Kundharu Saddhono. (2017). Local wisdom values in Sayu Wiwit folklore as the revitalization of behavioral education. Karsa: Journal of Social and Islamic Culture. Vol. 25 No.1, June 2017, 179-199 Retrieved from http://ejournal.stainpamekasan.ac.id/index.php/karsa/article/downloa d/1266/999

7. Hasnul Fikri. (2015). Tradisi bercerita masyarakat Kecamatan Mungka Kabupaten Lima Puluh Kota Provinsi Sumatera Barat. Salingka: Majalah Ilmiah Bahasa dan Sastra Volume 12 Nomor 2. Edisi Desember 2015, 233-242

8. Kleden, L. 1997. "Teks, cerita, dan transformasi kreatif". Jurnal Kebudayaan Kalam, Edisi X.

9. Lexy J. Moleong. (2002). Metode Penelitian Kualitatif. Bandung Remaja Rosda Karya.

10. Ngismatul Khoeriyah, Warto, \& Sariyatun. 2017. Learning history integrated local wisdom values "babad Banyumas" to build a student's national identity. SHS Web of Conferences 42, 00091 (2018). Retrieved from https://doi.org/10.1051/shsconf/ 20184200091.

11. Nyoman Kutha Ratna, (2009). Stilistika: Kajian Puitika Bahasa, Sastra, dan Budaya. Yogyakarta: Pustaka Pelajar

12. Rina Ratih. (2016). Teori dan Aplikasi Semiotik Machael Riffaterre Yogyakarta: Pustaka Pelajar.

13. Saifur Rahman. (2012). Pengantar Metodologi Pengajaran Sastra. Yogyakarta: Ar-Ruzz Media

14. Sapardi Djoko Damono. (2002). Sosiologi sastra. Jakarta: Gramedia.

15. Silvia Rosa (2017) Rabab Pasisia Selatan di Minangkabau di ambang kepunahannya. Lokabasa, 8 (1). 73-85. Retrieved from http://repo.unand.ac.id/5342/1/Rabab\%20 Pasisia\%20.pdf

16. Soeratno. (2011). Sastra: Teori \& Metode. Yogyakarta: Jurusan Sastra Indonesia Fakultas Ilmu Budaya UGM, Program S-2 Ilmu Sastra Fakultas Ilmu Budaya UGM, dan Penerbit Elmatera.

17. Sony Sukmawan. (2018). Environmental wisdom in oral literature of Arjuna slopes people. Lingua Cultura, 12 (1). 1-7. Retrieved from https://doi.org/10.21512/lc.v12i1.1459

18. Suwardi Endraswara. (2011). Metodologi Penelitian Sastra Bandingan. Bandung: Bukupop.

19. https://id.wikipedia.org/wiki/Emral_Djamal_Datuk_Rajo_Mudo

\section{GLOSSARY}

alua jo patuik = procedure, way and proper balai adat $=$ customary hall of Minangkabau bundo kanduang = queen mother

darek = inland located on the eastern part of Province of Sumatra Barat, Indonesia

$\mathrm{kaba}=$ traditional oral narrative in Minangkabau community, Province of Sumatera Barat, Indonesia

kaba pusako $=$ kaba which contains historical events inherited from generation to generation 
ninik mamak = traditional institution consisting of several penghulu who come from different clan that exist in the Minangkabau

pakaba = kaba narrator

pengulu = leader, power holder in Minangkabau customary

pesisir $=$ coastal areas along the coast in the western part of Province of Sumatera Barat, Indonesia

randai $=$ traditional theatre in Minangkabau community that combined theatre, music, and dance

raso jo pareso $=$ taste and check

rabab $=$ one of the tradition of telling kaba in Minangkabau by using a stringed musical instrument that is similar to a violin.

rumah gadang $=$ custom home of Minangkabau

saiyo-sakato = agreement, one word one action

sapikua sajinjiang = equally carrying together

silat $=$ traditional self-defense in Minangkabau

tukang kaba = kaba narrator

tukang rabab $=$ rabab player and some time as a singer too

\section{Author Profile}

Hasnul Fikri, currently I am associated with Universitas Bung Hatta Jl. Bagindo Aziz Chan, By Pass, Aie Pacah, Padang Sumatera Barat, Indonesia, my area of research is social sciences. 